Metalozn. obrobka met. 2019, vol. 25 (92), 21-25

https://doi.org/10.15407/mom2019.04.021

UDC 691.87:691.714

\title{
Reason of destruction side frame of the trolley
}

\author{
I. A. Vakulenko, Doctor of Technical Sciences, Professor, ihor@ukr.net \\ L. I. Vakulenko*, Ph.D. \\ S. V. Proydak, Ph.D., Associate professor
}

\author{
Dnipro National University of Railway Transport named after Academician \\ V. Lazaryan, Ukraine, Dnipro \\ * Management of the Dnieper Railway, Ukraine, Dnipro
}

The metallographic and fractographic analysis methods were used to study the influence of the cast metal quality on the causes of the destruction of a railway carriage under high dynamic and cyclic loads.

As a result of study structure fracture surface of the side frame freight car truck, the detected elements indicate simultaneous presence of fatigue and static fracture. The focus of nucleation fatigue crack was a surface defect of casting origin such as a blockage. Volumes with a concentrated arrangement of gas bubbles and non-metallic inclusions of various nature was found in the individual elements of the side frame. As a result of acceleration of moving fatigue crack, there are achievements of continuous decrease of construction of strength side frame. The meeting of the fatigue crack with volumes metal with an increased concentration of gas bubbles and non-metallic inclusions accelerated the transition to the phase of static fracture. Improving the operational safety of the side frame is possible by improving the foundry technology of its manufacture and changing the regulatory documentation to limit non-metallic inclusions and pores in the metal.

Key words: crack, fatigue, fracture, non-metallic inclusions, pores.

$\mathrm{T}$ he increasing intensity of freight transport by rail requires the development of measures to improve operational safety. A component in the complex process of developing such measures is the explanation of the reasons for premature withdrawal of rolling stock from service. Increasing the profitability of transportation by increasing the axle load indicates need to revise requirements for materials used for the manufacture of rolling stock. In addition to the chemical composition, for the majority of low-carbon steels, the final structural state of the product after its completion is significant. Rolled products with a structural state after hot reduction or thermal hardening in a rolling mill line, according to most indicators, have a higher range of properties than obtained by casting technology [1]. An example is the side frame of a freight car truck, which is manufactured by casting. The resistance of the destruction side frame metal is determined by the combined effect of factors. One of them is the rather frequent exceeding restrictions of normative documentation on nonmetallic inclusions, pores, gas bubbles various nature of origin, their shape and 
location in metals. The known results of study causes of destruction products manufactured by foundry technologies, the most likely places for the formation of destruction center are metal volumes with a concentrated arrangement of those defects [2].

Explanation of the cause destruction of the side frame trolley during operation of the railway transport.

The material for the study was $20 \mathrm{GL}$ steel after sampling from the side frame of the freight wagon trolley after destruction. The chemical composition of steel, determined by the "Spectrolab" spectrometer was: $0.19 \% \mathrm{C} ; 1.14 \%$ $\mathrm{Mn} ; 0.38 \% \mathrm{Si} ; 0.01 \% \mathrm{P} ; 0.039 \% \mathrm{~S} ; 0.019 \% \mathrm{Ni} ; 0.074 \% \mathrm{Cr} ; 0.113 \% \mathrm{Cu}$. The microstructure was investigated using light microscopy techniques [3]. The study of the fracture surface was carried out in accordance with the methods of fractographic analysis [2]. The complex of mechanical properties was determined by the methods and on samples in accordance with the requirements of OST.32.183-2001.

Based on a comprehensive study metal of the side frame trolley, the steel according to non-metallic inclusions (Fig. 1a), microstructure (Fig. 1b), and mechanical characteristics generally met the requirements of OST 32.1832001 .

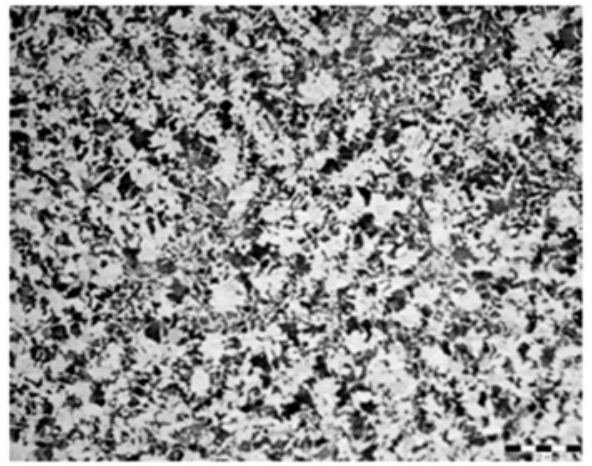

a

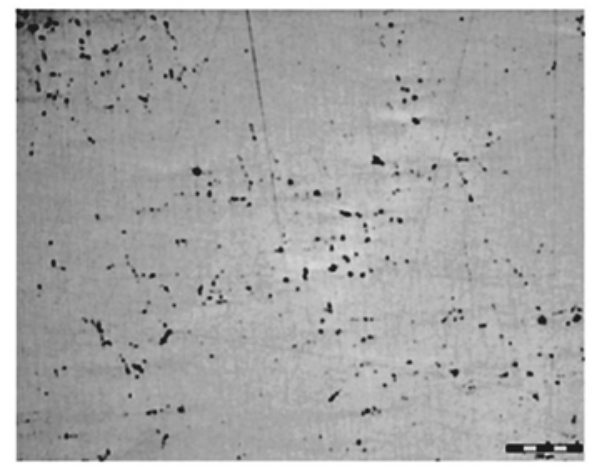

б

Fig. 1. Microstructure of steel (a), line and point nitrides (b).

A general view of the fracture surface of the beam is shown in Fig.2a. Based on the analysis of fatigue lines location and the orientation of the formed steps [2, 4], the surface defect of foundry origin such as a blockage should be considered the focus of crack initiation (designation 2, Fig. 2b). A detailed study showed that this defect has exit to the outer surface of the side frame. The observed steps (designation 1, Fig. 2b) formed near the indicated inclusion and their gradual disappearance indicate the growth of a fatigue crack along several surfaces [2]. Moreover, after combining individual fronts into one, the fracture process develops with increasing speed, which is confirmed by an increase in the distance between stops of the fatigue crack (designation 3 , Fig. 2b). After reducing the constructive strength of the side frame from the fatigue crack, conditions begin to create the transition crack growth process to the next stage. Given that after the completion of incubation phase of the crack growth, which corresponds to low values of the stress intensity factor at 


\section{Структура, зношування, руйнування}

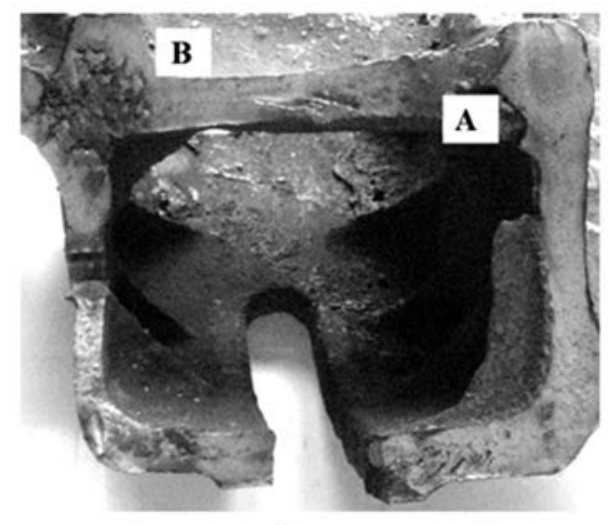

a

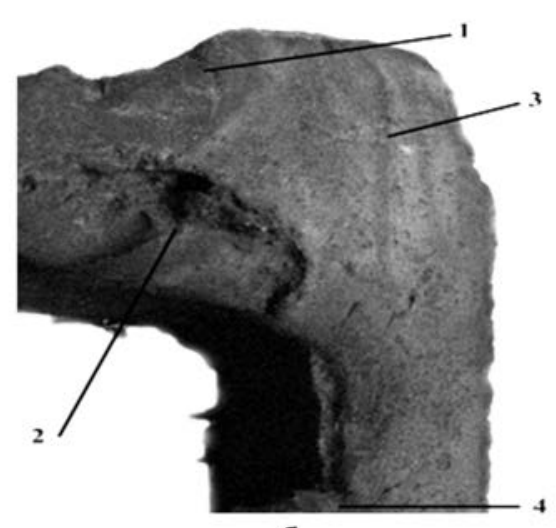

б

Fig. 2. General view of the fracture surface side frame (a) and selected area (A) with place of origin fatigue crack (b): 1 - steps, 2 - non-metallic inclusion, 3 - front of the fatigue crack, 4 - signs of static fracture.

mouth crack [5], qualitative changes in the nature of crack propagation are associated with an increase of cyclic loading amplitude. At the same time signs of cycle fatigue static component (facets, ridges, etc.) begin to appear on the fracture surface [2], with a simultaneous increase of length of crack front moving. Indeed, when analyzing the fracture surface, especially in part where the stage of fatigue crack growth ends on one surface (designation 4, Fig. 2b), the signs similar radial component of static fracture are found [4]. In this case, the successive formation of the ridges and fine facets occurs.

The asymmetric location of the crack nucleation center relative to the side walls of the frame (Fig. 2a) should lead to the differences in crack growth on the opposite walls, which was actually confirmed by the traces from the front of fatigue crack. In a first approximation, it can be assumed that the simultaneous presence of nonmetallic inclusions and increased metal porosity (symbols 1 and 2, Fig. 3) along the crack propagation path caused a violation of its growth conditions [6]. Similar cases of influence are known from the results of studies of the fracture surfaces [2]. Based on this, as a result of decrease in the constructive strength of the side frame from the presence of pores, the amplitude of cycle quickly reached a level for the transition process of metal fracture to the phase of final dynamic destroy. This is indicated by the presence of steps on the fracture surface and a change in the direction of movement crack front [7].

Thus, the evidence of formation and development destruction indicates that improving the operational safety of the side frame of the wagon trolley is possible due to the improvement of casting technology. At the same time, the development of amendments to the normative documentation to further limit the presence of non-metallic inclusions and pores in the metal should be considered as an additional factor in increasing the life of the side frame.

The cause of fracture side frame of the trolley is crack of fatigue in the corner of region radius R55 on the inner side of the supporting surface from the presence of a non-metallic inclusion, with a size significantly exceeding regulatory restrictions. 


\section{Структура, зношування, руйнування}

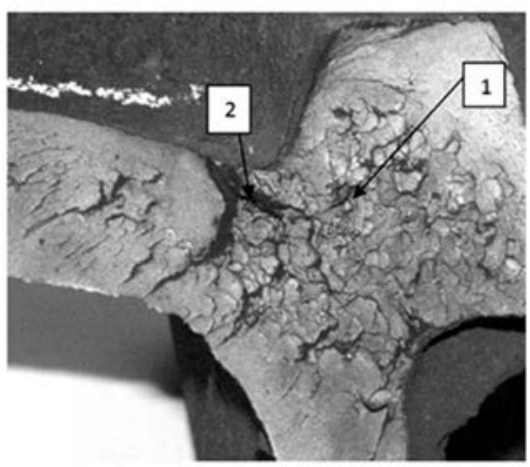

a

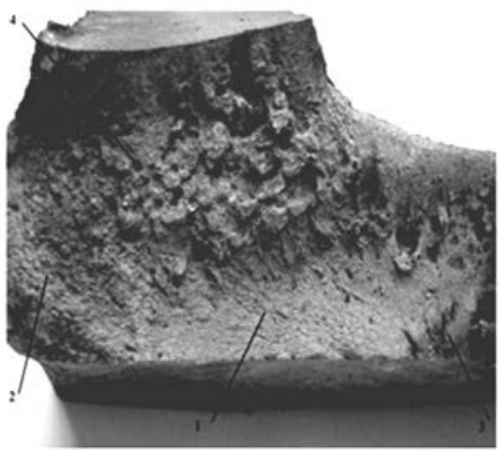

б

Fig. 3. The fracture surface (region B, Fig. 2a) with an increased concentration of non-metallic inclusions (1) and porosity (2) - (a); brooky pattern (1), facets (2), secondary crack (3) and metal discontinuities (4) - (b).

The presence in a separate volume metal of a side frame of the trolley concentrated porosity and non-metallic inclusions of various nature of origin was the reason for accelerated transition fracture process to the phase of a static destruction.

\section{Література}

1. Fracture. An Advanced Treatise. Volume VI (Fracture of metals). Edit. H. Liebowitz. Academic Press, N-York and London, 1969.

2. Fractography and Atlas of Fractographs. Metals handbook, $8^{\text {th }}$ Edition $/ /$ American Society for Metals. - 1974. - Vol. 9.

3. Вакуленко I.О. Структурний аналіз в матеріалознавстві. - Дн-ськ: Маковецький, 2010. - 124 с.

4. Трощенко В.Т. Усталость и неупругость металлов. - К: Наукова думка, 1971. - 267c.

5. Усталость и вязкость разрушения. Ред. Иванова В.С., Гуревич С.Е. - М.: Наука, 1974. - 282c.

6. Vakulenko I., Vakulenko L., Proydak S. The influence of nonmetallic inclusion on strain hardening carbon steel. Scientific Jou rnal of Silesian University of Technology / Transport. - 2019. - Vol.103. - P.193-198. https://doi.org/10.20858/sjsutst.2019.103.15

7. Vakulenko I., Lisnyak A., Griaznova L., Bolotova D. Influence of shock wave treatment on fatigue carbon steel. Proc. Enter disci plinary Sci. Conf. "Multifactor approaches to the formation of a comfortable environment“, Netanya, Israel, 2017. - P.142-154.

\section{References}

1. Fracture. An Advanced Treatise. Volume VI (Fracture of metals). Edit. H. Liebowitz. Academic Press, N-York and London, 1969 [in English].

2. Fractography and Atlas of Fractographs. Metals handbook, $8^{\text {th }}$ Edition, vol. 9. American Society for Metals, 1974 [in English].

3. Vakulenko I.O. Strukturniyj analiz v materialoznavstvi (Structural analysis in metal science), Donetsk, Makovecjkiyj, 2010, 124 p. [in Ukrainian].

4. Trothenko V.T. Ustalostj i neuprugost metallov (Fatigue and inelasticity of metals), Kyiv, Naukova dumka, 1971, 267 p. [in Russian].

5. Ivanova V.S.,Gu revich S.E Ustalost i vyazkostj razrusheniya (Fatigue and viscous fracture),Moskva,Nauka,1974,282 p. [in Russian].

6. Vakulenko I., Vakulenko L., Proydak S. The influence of nonmetallic inclusion on strain hardening carbon steel. Scientific Jou rnal of Silesian University of Technology, 2019, Vol.103, pp.193-198 [in English]. https: / / doi.org/10.20858/sjsutst.2019.103.15. 


\section{Структура, зношування, руйнування}

7. Vakulenko I., Lisnyak A., Griaznova L., Bolotova D. Influence of shock wave treatment on fatigue carbon steel. Proc. Enter disci plinary Sci. Conf. "Multifactor approaches to the formation of a comfortable environment", Netanya, Israel, 2017, pp.142-154 [in English].

\section{И. А.Вакуленко, Л. И. Вакуленко, С. В. Пройдак \\ О причине разрушения боковой рамы тележки вагона}

Резюме

Методами металлографического и фракторгафичного анализа исследовано влияние качества литого металла на причины разрушения тележки железнодорожного вагона в условиях эксплуатации высоких динамических и циклических нагрузок.

В результате исследования строения поверхности разрушения боковой рамы тележки грузового вагона из стали 20ГЛ, обнаруженные элементы указывают на одновременное присутствие усталостного и статического разрушения. Очагом зарождения усталостной трещины явился поверхностный дефект литейного происхождения типа засора. В отдельных элементах боковой рамы обнаружены объемы с сосредоточенным расположением газовых пузырей и неметаллических включений различной природы происхождения. В результате продвижения усталостной трещины происходило непрерывное снижение конструктивной прочности боковой рамы, а встреча с объемами металла с повышенной концентрацией газовых пузырей и неметаллических включений ускорила переход в фазу статического разрушения. Повышение эксплуатационной безопасности боковой рамы возможно за счет совершенствования литейной технологии ее изготовления и изменения нормативной документации по ограничению неметаллических включений и пор в металле.

Ключевые слова: трещина, усталость, разрушение, неметаллические включения, поры.

\section{І. О. Вакуленко, Л. І. Вакуленко, С. В. Пройдак Про причини руйнування бічної рами візка вагона}

\section{Анотація}

Методами металографічного і фракторгафічного аналізу досліджено вплив якості литого металу на причини руйнування візка залізничного вагону за умов експлуатації високих динамічних і циклічних навантажень.

В результаті дослідження поверхні руйнування бокової рами візка вантажного вагона зі сталі 20ГЛ виявлені елементи, що вказують на одночасну присутність втомного і статичного руйнування. Осередком зародження тріщини втоми був поверхневий дефект ливарного походження типу засору. В окремих елементах бокової рами виявлені об'єми з зосередженим розташуванням газових порожнин і неметалевих включень різної природи походження. В результаті просування тріщини втоми відбувалося безперервне зниження конструктивної міцності бокової рами, а зустріч ï̈ з об'ємами металу з підвищеною концентрацією газових порожнин і неметалевих включень прискорила перехід в фазу статичного руйнування. Підвищення експлуатаційної надійності бокової рами можливе за рахунок вдосконалення ливарної технології іiі виготовлення та внесення змін у нормативну документацію щодо обмеження вмісту неметалевих включень і пор у металі.

Ключові слова: тріщина, втома, руйнування, неметалеві включення, пори. 